\title{
Antidiabetic and Antioxidant Activities of Ethanolic Extract of Dried Flowers of Moringa oleifera in Streptozotocin-induced Diabetic Rats
}

\author{
Rotimi Olusanya Arise ${ }^{1}$, Oluwaseun Ruth Aburo ${ }^{1,2}$, Samuel Tobi Farohunbi ${ }^{1}$, \\ Adenike Adebola Adewale ${ }^{1,3}$ \\ ${ }^{1}$ Department of Biochemistry, University of Ilorin, P.M.B. 1515, Ilorin, Nigeria \\ ${ }^{2}$ Department of Biochemistry, Afe Babalola University, Ado Ekiti, Ekiti, Nigeria \\ ${ }^{3}$ Department of Biochemistry, Bowen University, Iwo, Osun State, Nigeria
}

\section{SUMMARY}

This study was undertaken to determine the antidiabetic and antioxidant effects of oral administration of ethanolic extract of Moringa oleiferaflower on stretozotocin-induced diabetic rats at 100, 200 , and $300 \mathrm{mg} / \mathrm{kg}$ b.w.

Thirty (30) male experimental albino rats were grouped randomly into six groups: groups A, B, and $\mathrm{F}$ are the control, diabetic control and reference drug groups, while C-E received 100,200 , and $300 \mathrm{mg} / \mathrm{kg}$ b.w of the extract, respectively. Blood samples and organs were collected to assay for blood glucose level and antioxidant enzymes.

Levels of blood glucose, serum lipids and lipid peroxidation as well as aspartate aminotransferase (AST), alkaline phosphatase (ALP), and alanine aminotransferase (ALT) activities were significantly reduced $(\mathrm{p}<0.05)$ in STZ-induced diabetic rats orally administered ethanolic extract of M. oleifera flower. However, the body weight; catalase and superoxide dismutase activities were significantly increased ( $\mathrm{p}<$ $0.05)$ when compared with the controls.

M. oleifera flower ethanolic extract administered orally therefore exhibited improved lipid metabolism, glucose-lowering potential and is hence beneficial in preventing diabetic complications as a result of lipid peroxidation and oxidative systems in streptozotocin-induced diabetic rats. It could thus be employed therapeutically in managing diabetes mellitus.

Key words:ethanolic extract, antidiabetic, antioxidant enzymes, Moringa oleifera, streptozotocin

Corresponding author:

Rotimi Olusanya Arise

Email: ariserotimi@gmail.com 


\section{INTRODUCTION}

Diabetes mellitus, a complex multisystem and metabolic disorder is characterized by relative or absolute defects in insulin secretion and disturbances in carbohydrate, protein and lipid metabolism (1). The world population with diabetes is rising yearly and by the year 2030, it is expected to hit 439 million (2). Diabetes mellitus has been classified into two major types: type 1 is also referred to as insulin-dependent diabetes mellitus (IDDM) and type 2 is referred to as non-insulin-dependent diabetes mellitus (NIDDM). Type I diabetes, an autoimmune disease, normally presents with local inflammatory reactions in and around islets, which results in the selective destruction of $\beta$-cells that secrete insulin. Peripheral insulin resistance and impaired insulin secretion are seen in type 2 diabetes (3).

Diabetes mellitus has been shown to be associated with oxidative stress, leading to an increased production of reactive oxygen species (ROS) such as hydroxyl radical $(\mathrm{OH} \bullet)$, hydrogen peroxide $\left(\mathrm{H}_{2} \mathrm{O}_{2}\right)$, and superoxide anion radical $\left(\mathrm{O}_{2} \bullet-\right)$ or diminished availability of endogenous antioxidants. In addition to oxygen free radical generation, non-enzymatic protein glycosylation, formation of peroxides and autooxidation of glucose have contributed to the involvement of oxidative stress in the pathogenesis of diabetes mellitus $(4,5)$. Lipid peroxidation (LPO), a key marker of oxidative stress induced by free radicals results in the oxidative worsening of poly-unsaturated fatty acids that consequently results in massive membrane damage and dysfunction (6).

The various endogenous antioxidants in cells help to prevent or mend the damage caused by free radicals, and also serve to regulate signaling pathways that are redox-sensitive. Superoxide radicals are inactivated through conversion to hydrogen peroxide and molecular oxygen by the superoxide dismutase, and hydrogen peroxide is itself converted to water by catalase and peroxidases causing membrane destabilization, damages to DNA and proteins, and oxidation of low-density lipoprotein (LDL); ROS are implicated in mutagenesis, cellular aging, carcino-genesis, and coronary heart disease (6) Moreover, increased LPO in diabetics can be due to an upsurge in oxidative stress in the cell due to a weakened anti-oxidant protective systems (7).

Plants are known to be rich in natural antioxidants such as carotenoids, tocopherols, flavonoids, vitamin C and several other phenolic compounds (8). Ethnobotanical information has it that plants numbering more than 800 are in use traditionally for treating diabetes owing to their potency, fewer side effects, and cheapness (9). Through their normoglycemic effect, ability to improve lipid metabolism, antioxidant defense system and capillary function, botanical products can enhance glucose metabolism and the overall condition of individuals with diabetes (10).

Moringa oleifera, a tropical highly treasured plant, is found in several countries of the tropical and subtropical regions. It is a perennial softwood tree with low quality timber belonging to the single genus family Moringaceae. It is a small, rapidly developing ornamental tree which is believed to be of Indian origin. Several parts of the tree including its root, pods, bark, and leaves are of importance in traditional medicine for treating human diseases, whereby the leaves are enriched in $A$ and $C$ vitamins. The therapeutic effects of $M$. oleifera include: antibiotic (11), anticancer (12), antiulcerogenic (13), analgesic (14), antiurolithiatic (15) and larvicidal (16). Parts of the plant including the roots, seed, leaves, bark, fruit, immature pods and flowers act as cardiac and circulatory stimulants, possess antitumor (17), antipyretic, anti-inflammatory, antiepileptic and antiulcer properties (18). It is also known to be antisplasmodic (19), diuretic (20), antihypertensive (21), antihyperlipdaemic (22), hepatoprotective, antioxidant, antidiabetic, (23), antifungal and antibacterial (24). Highly appreciable levels of four natural antioxidants of dietary origin: vitamins $\mathrm{A}, \mathrm{C}$ and $\mathrm{E}$ and phenolics are found in M. oleifera. Studies have estimated 46 antioxidants in Moringa which are important to cells in combating free radicals (25-27). This study was therefore aimed at investigating the effect of ethanolic extract of dried flowers of M. oleifera in streptozotocin-induced diabetes in rats.

\section{MATERIALS AND METHODS}

\section{Chemicals used}

Streptozotocin (STZ) was a product of Sigma Chemical Company (USA). The assay kits for cholesterol, LDL, HDL, triglyceride, ALT, AST were products of Randox Laboratory Ltd, Co-Atrim (UK). Glibenclamide was a product of TuyilPharmaceuticals Limited, Nigeria. All other reagents used were of analytical grades. 


\section{Plant material}

The freshly harvested flower of $M$. oleifera was a gift from the University of Ilorin Moringa Plantation in Ilorin, Kwara State, Nigeria, and was identified at the Herbarium Unit, Plant Biology Department, University of Ilorin, Nigeria, where herbarium specimen was deposited with Voucher Specimen Number: U.I.H 002/1008.

\section{Phytochemical screening}

A preliminary phytochemical screening of the flowers of $M$. oleifera was conducted using a standard method of analysis as described by Sofowora (28).

\section{Extract preparation}

Fresh flowers of $M$. oleifera were air-dried at $40^{\circ} \mathrm{C}$ using Uniscope SM9053 laboratory Oven, Surgifriend Medicals, England. The dried flowers (161 g) were then pulverized using an electric blender (Crown Star Blender CS-242B, Trident (H.K) Ltd, China) after which the resulting powder was extracted in $95 \%$ ethanol for 72 hours at $37{ }^{\circ} \mathrm{C}$ with continuous shaking. This extract was then filtered using Whatman No 1 filter paper and the filtrate obtained was concentrated in a water bath at $40^{\circ} \mathrm{C}$. The extract was stored in a refrigerator at $-4^{\circ} \mathrm{C}$. Calculated amounts were reconstituted in distilled water to give the required doses of 100, 200, and 300 $\mathrm{mg} / \mathrm{kg}$ body weights used for oral administration.

\section{Experimental animals}

Thirty male experimental albino rats (Rattusnorvegicus) of weight $151 \pm 5.00 \mathrm{~g}$ obtained from the Animal Holding Unit of Biochemistry De-partment, University of Ilorin, Ilorin, Nigeria were acclimatized for 2 weeks before the experiment. The animals were housed in clean wooden cages, fed standard diets and were allowed unhindered access to water with regulated $12 \mathrm{~h}$ light/dark cycle.

\section{Induction of diabetes}

Diabetes was induced via intra-peritoneal injection of $45 \mathrm{mg} / \mathrm{kg}$ body weight of freshly prepared streptozotocin (STZ). STZ was prepared in citrate buffer (0.1M, pH 4.5). Prior to diabetes induction, the animals were fasted overnight and the overnight fasted-rats were confirmed diabetic by measuring blood glucose concentration $96 \mathrm{~h}$ after injection with STZ using Accu-Chek glucometer. Rats belonging to the non-diabetic control group were injected with just citrate buffer. Blood sample was obtained from tail puncture of the rats for the fasting blood glucose determination, and animals with blood glucose values greater than $200 \mathrm{mg} / \mathrm{dL}$ were considered diabetic; blood glucose level was checked every day for 7 days. Treatment was commenced on the fifth day post-STZ injection and was considered the first day of treatment. For a period of 21 days, the treatment persisted.

\section{Animal grouping}

Group A: Control rats received $1 \mathrm{ml}$ of distilled water once daily.

Group B: Diabetic control rats received $1 \mathrm{ml}$ of distilled water once daily.

Groups C: STZ-induced diabetic rats administered $100 \mathrm{mg} / \mathrm{kg}$ body weight ethanolic extract of $M$. oleifera flower once daily.

Group D: STZ-induced diabetic rats treated with $200 \mathrm{mg} / \mathrm{kg}$ body weight ethanolic extract of $M$. oleifera flower once daily.

Group E: STZ-induced diabetic rats treated with $300 \mathrm{mg} / \mathrm{kg}$ body weight ethanolic extract of $M$. oleifera flower once daily.

Group F: STZ-induced diabetic rats treated with standard antidiabetic drug (glibenclamide 5 $\mathrm{mg} / \mathrm{kg}$ body weight) once daily.

Collection of blood samples and serum preparation

After the 21-day treatment, the animals were anaesthetized with ethyl ether and sacrificed by simple incision of the jugular vein, the blood samples were collected into clean, dry, sample bottles for serum analyses. Blood samples were left undisturbed to clot at room temperature for 30 minutes and then centrifuged at $1000 \mathrm{rpm}$ for a period of 15 minutes using Uniscope Laboratory centrifuge (Model SM800B, Surgifriend Medicals, Essex, England). After centrifugation, the supernatants (sera) were aspirated using a Pasteur's pipette. The sera, thus obtained, were appropriately labelled and stored in a freezer at $5^{\circ} \mathrm{C}$ until required for further analysis. 


\section{Preparation of tissue homogenate}

Tissues (liver, kidney, and pancreas) were isolated from the dissected rats. The isolated tissues were cleansed with blotting paper to remove blood stains, weighed and stored immediately in ice cold $0.25 \mathrm{M}$ sucrose solution. Specific weight of the liver, pair of kidney, and pancreas were then subjected to homogenization using mortar and pestle in ice-cold $0.25 \mathrm{M}$ sucrose solution $(1: 5 \mathrm{w} / \mathrm{v})$. At a speed of $4000 \mathrm{rpm}$, the homogenates were centrifuged for 10 minutes and the supernatants were siphoned into appropriately labelled sample bottles and stored in the freezer $\left(-20^{\circ} \mathrm{C}\right)$ until needed for further analysis.

\section{Assay of biochemical parameters}

Serum total cholesterol (TC), triglycerides (TG), low density lipoprotein (LDL-C), high density lipoprotein (HDL-C), alanine transaminase (ALT) and aspartate aminotransferase (AST) were determined using the standard kit of Randox laboratories, CoAtrim, UK. Malondialdehyde, catalase and superoxide dismutase were estimated using the methods described by Jiang et al. (29), Aebi (30) and Misra and Fridovich (31), respectively. Alkaline phosphatase activity was estimated using the method described by Wright et al. (32). All spectrophotometric measurements were carried out in a Camspec UV-Visible spectrophotometer. The determinations were replicated 5 times $(n=5)$.

\section{STATISTICAL ANALYSIS}

Results were presented as mean of replicates \pm SD. Means were analyzed using a one-way analysis of variance (ANOVA), followed by the Duncan Multiple Range Test to determine significant differences in all the parameters. Differences with values of $p<0.05$ were considered statistically significant (33).

\section{RESULTS}

\section{Phytochemical screening}

Table 1 shows the result of preliminary phytochemical screening of $M$. oleifera flowers extract. Flavanoids, alkaloids, tannins, phenolics, terpenoids, cardiac glycoside, cardenolides and dienolides were present.
Table 1: Phytochemical constituents of Moringa oleifera flower

\begin{tabular}{lc}
\hline \multicolumn{1}{c}{ Phytochemical } & Inference(+/-) \\
\hline Anthraquinones & - \\
\hline Tannins & + \\
\hline Phenolics & + \\
\hline Saponins & - \\
\hline Terpenoids & + \\
\hline Alkaloids & + \\
\hline Steroids & - \\
\hline Cardiac glycoside & + \\
\hline Flavonoids & + \\
\hline Triterpenes & - \\
\hline Cadenolides and & + \\
Dienolides & \\
\hline \hline
\end{tabular}

Key: + Presence of constituents, - Absence of constituents

Blood glucose

Table 2 shows the effect of ethanolic extract of $M$. oleiferaon fasting blood glucose levels of rats induced with diabetes via STZ injection. Blood glucose level was significantly elevated $(p<0.05)$ after induction of diabetes in STZ-induced diabetic rats relative to the control group. However, a significant decrease ( $p<0.05$ ) was noted at $100,200,300 \mathrm{mg} / \mathrm{kg}$ of ethanolic extract of $M$. oleifera flower which produced more than $70 \%$ reduction in glucose level within 2 weeks of administration.

\section{Body weight}

Presented in Table 3 is the effect of $M$. oleiferae thanolic extract on weight gain of rats induced with diabetes via STZ injection. A significant reduction $(\mathrm{p}<$ 0.05 ) in body weight was noticed in the diabetic rats. STZ diabetic rats lost $35.6 \mathrm{~g}$ of body weight by the $21^{\text {st }}$ day post-induction of diabetes, while non-diabetic animals gained $79.20 \mathrm{~g}$ during this period. Glibenclamide-treated diabetic rats also gained weight, but this weight gain (66 g) was less than that of the control animals. Diabetic rats administered ethanolic extract of $M$. oleifera flower and glibenclamide showed significantly increased $(p<0.05)$ body weight gain to near-control level.

Serum lipid profile

Table 4 shows the effects of administration of ethanolic extract of $M$. oleifera on serum lipid profileof 
Table 2: Effects of ethanolic extract of M. oleiferaon fasting blood glucose level of STZ- induced diabetic rats

\begin{tabular}{c|c|c|c|c}
\hline \hline \multirow{2}{*}{ Group } & \multicolumn{4}{|c}{ Blood glucose (mg/dL) } \\
\cline { 2 - 5 } & $\begin{array}{c}\text { After } \\
\text { Induction }\end{array}$ & Week 1 & Week 2 & Week 3 \\
\hline A & $76.20 \pm 6.87^{\mathrm{a}}$ & $77.67 \pm 5.86^{\mathrm{a}}$ & $73.00 \pm 3.72^{\mathrm{a}}$ & $83.80 \pm 3.83^{\mathrm{a}}$ \\
\hline $\mathrm{B}$ & $269.67 \pm 18.04^{\mathrm{b}}$ & $290.20 \pm 25.40^{\mathrm{c}}$ & $297.67 \pm 63.01^{\mathrm{b}}$ & $326.40 \pm 28.9^{\mathrm{b}}$ \\
\hline $\mathrm{C}$ & $331.00 \pm 18.00^{\mathrm{b}}$ & $179.00 \pm 11.52^{\mathrm{b}}$ & $83.33 \pm 5.08^{\mathrm{a}}$ & $85.00 \pm 8.10^{\mathrm{a}}$ \\
\hline $\mathrm{D}$ & $287.20 \pm 19.19^{\mathrm{b}}$ & $170.67 \pm 0.58^{\mathrm{b}}$ & $78.00 \pm 4.00^{\mathrm{a}}$ & $71.00 \pm 6.20^{\mathrm{a}}$ \\
\hline $\mathrm{E}$ & $336.40 \pm 15.90^{\mathrm{b}}$ & $162.00 \pm 12.00^{\mathrm{b}}$ & $82.33 \pm 2.83^{\mathrm{a}}$ & $70.80 \pm 7.16^{\mathrm{a}}$ \\
\hline $\mathrm{F}$ & $266.20 \pm 21.00^{\mathrm{b}}$ & $158.00 \pm 10.51^{\mathrm{b}}$ & $78.33 \pm 1.45^{\mathrm{a}}$ & $77.60 \pm 7.60^{\mathrm{a}}$ \\
\hline \hline
\end{tabular}

Values are means $(n=5) \pm S D$. (Values with different superscript are significantly different at $\mathrm{p}<0.05$ ).

Group A: Control; Group B: Diabetic Control; Group C: Diabetic + (100 mg/kg body weight); Group D: Diabetic + (200 mg/kg body weight); Group E: Diabetic + (300 mg/kg body weight); Group F: Diabetic + (5 mg/kg body weight of glibenclamide).

STZ-induced diabetic rats. The values of TG, HDL-C, LDL-C, TC and atherogenic index of STZ-induced diabetic rat significantly increased $(p<0.05)$ while groups treated with ethanolic extract of $M$. oleifera flower restored their values to near-control levels. Serum lipid profile of STZ-induced diabetic rats treated with ethanolic extract of $M$. oleifera flower was not significantly different $(p>0.05)$ from the control except group $E$ which had a significantly elevated ( $\mathrm{p}<$ 0.05 ) serum lipid profile when compared with control.

\section{Antioxidant parameters}

Table 5 presents the effect of oral administration of ethanolic extract of $M$. oleifera flower on liver, kidney and pancreas malondi-aldehyde concentration in the rats induced with diabetes via STZ injection. There was a significant decrease $(p<0.05)$ in liver, kidney and pancreas malondialdehydeconcentration of all STZ-induced diabetic rats treated with ethanolic extract of $M$. oleifera flower.

Table 6 shows the effects of oral administration of ethanolic extract of $M$. oleifera flower on liver, kidney and pancreas SOD activity of rats induced with diabetes using STZ. A significant decrease ( $p$ $<0.05$ ) in the liver, pancreas and kidney SOD activities of all STZ-induced diabetic groups relative to the control was observed. However, there was a significant elevation $(p<0.05)$ in the liver, kidney and pancreas SOD activity of STZ-induced diabetic rats treated with ethanolic extract of $M$. oleifera flower.
Table 3: Effects of ethanolic extract of M. oleiferaon the body weight ofSTZ-induced diabetic rats

\begin{tabular}{lc}
\hline Group & $\begin{array}{c}\text { Changes in body } \\
\text { weight }(\mathrm{g})\end{array}$ \\
\hline A & $79.20 \pm 3.83^{\mathrm{a}}$ \\
\hline B & $35.6 \pm 4.62^{\mathrm{b}}$ \\
\hline C & $56.4 \pm 3.08^{\mathrm{a}}$ \\
\hline D & $60.4 \pm 2.06^{\mathrm{a}}$ \\
\hline E & $53.8 \pm 3.27^{\mathrm{a}}$ \\
\hline F & $66.0 \pm 3.8^{\mathrm{a}}$ \\
\hline \hline
\end{tabular}

Values are means $(n=5) \pm$ SD. (Values with different superscript are significantly different at $\mathrm{p}<0.05)$.

Group A: Control; Group B: Diabetic Control; Group C: Diabetic + (100 mg/kg body weight); Group D: Diabetic + (200 mg/kg body weight); Group E: Diabetic + (300 mg/kg body weight); Group F: Diabetic + $(5 \mathrm{mg} / \mathrm{kg}$ body weight of glibenclamide).

Table 7 presents the effects of the oral administration of ethanolic extract of $M$. oleifera flower on liver, kidney and pancreas catalase (CAT) activity of STZ-induced diabetic rats. There was a significant decrease $(p<0.05)$ in catalase activity in the liver, kidney and pancreas of all STZ-induced diabetic groups with respect to the control, while there was a significant increase $(p<0.05)$ in catalase activity of the liver, pancreas and the kidney in all STZ-induced diabetic rats administered ethanolic extract of $M$. oleifera flower. 
Table 4: Effects of ethanolic extract of M. oleiferaon serum lipid profile of STZ-induced diabetic rats

\begin{tabular}{cccccc}
\hline \hline Group & TC (mg/dL) & $\begin{array}{c}\text { HDL-C } \\
(\mathbf{m g} / \mathbf{d L})\end{array}$ & $\begin{array}{c}\text { LDL-C } \\
(\mathbf{m g} / \mathbf{d L})\end{array}$ & TG (mg/dL) & $\begin{array}{c}\text { Atherogenic } \\
\text { Index (LDL/HDL) }\end{array}$ \\
\hline A & $145.6 \pm 3.4^{\mathrm{a}}$ & $45.8 \pm 1.8^{\mathrm{a}}$ & $74.8 \pm 4.9^{\mathrm{a}}$ & $124.94 \pm 4.9^{\mathrm{a}}$ & $1.64 \pm 0.15^{\mathrm{a}}$ \\
\hline $\mathrm{B}$ & $287.8 \pm 20.6^{\mathrm{b}}$ & $54.6 \pm 5.0^{\mathrm{c}}$ & $192.7 \pm 12.4^{\mathrm{b}}$ & $202.9 \pm 18.1^{\mathrm{b}}$ & $3.53 \pm 0.20^{\mathrm{b}}$ \\
\hline $\mathrm{C}$ & $161.4 \pm 15.3^{\mathrm{a}}$ & $46.5 \pm 2.8^{\mathrm{ab}}$ & $79.5 \pm 5.4^{\mathrm{a}}$ & $142.8 \pm 6.0^{\mathrm{a}}$ & $1.86 \pm 0.14^{\mathrm{a}}$ \\
\hline $\mathrm{D}$ & $152.8 \pm 5^{\mathrm{a}}$ & $46.5 \pm 0.5^{\mathrm{ab}}$ & $79.5 \pm 3.0^{\mathrm{a}}$ & $133.8 \pm 13.1^{\mathrm{a}}$ & $1.71 \pm 0.09^{\mathrm{a}}$ \\
\hline $\mathrm{E}$ & $153.1 \pm 7.7^{\mathrm{a}}$ & $49.7 \pm 2.9^{\mathrm{b}}$ & $76.3 \pm 6.6^{\mathrm{a}}$ & $134.5 \pm 10.1^{\mathrm{a}}$ & $1.54 \pm 0.10^{\mathrm{a}}$ \\
\hline $\mathrm{F}$ & $154.3 \pm 12.0^{\mathrm{a}}$ & $45.3 \pm 0.5^{\mathrm{a}}$ & $84.2 \pm 6.6^{\mathrm{a}}$ & $123.8 \pm 11.8^{\mathrm{a}}$ & $1.86 \pm 0.15^{\mathrm{a}}$ \\
\hline \hline
\end{tabular}

Values are means $(n=5) \pm S D$. (Values with different superscript are significantly different at $p<0.05$ ).

Group A: Control; Group B: Diabetic Control; Group C: Diabetic + (100 mg/kg body weight); Group D: Diabetic + (200 $\mathrm{mg} / \mathrm{kg}$ body weight); Group E: Diabetic + (300 mg/kg body weight); Group F: Diabetic + (5 mg/kg body weight of glibenclamide).

Table 5: Effect of ethanolic extract of $M$. oleifera flower on malondialdehyde concentration in the liver, kidney and pancreas of STZ-induced diabetic rats

\begin{tabular}{c|c|c|c}
\hline \hline \multicolumn{4}{c}{ MDA (nmol/mg x 10-5) } \\
\hline Group & Liver & Kidney & Pancreas \\
\hline A & $0.89 \pm 0.30^{\mathrm{a}}$ & $0.53 \pm 0.05^{\mathrm{a}}$ & $0.65 \pm 0.02^{\mathrm{a}}$ \\
\hline B & $6.32 \pm 0.51^{\mathrm{b}}$ & $1.18 \pm 0.04^{\mathrm{c}}$ & $1.50 \pm 0.14^{\mathrm{c}}$ \\
\hline C & $2.71 \pm 0.21^{\mathrm{a}}$ & $0.39 \pm 0.03^{\mathrm{ab}}$ & $1.07 \pm 0.16^{\mathrm{ac}}$ \\
\hline D & $1.74 \pm 0.16^{\mathrm{a}}$ & $0.59 \pm 0.05^{\mathrm{a}}$ & $0.83 \pm 0.04^{\mathrm{a}}$ \\
\hline E & $2.36 \pm 0.2^{\mathrm{a}}$ & $0.74 \pm 0.04^{\mathrm{a}}$ & $0.24 \pm 0.01^{\mathrm{b}}$ \\
\hline F & $1.16 \pm 0.08^{\mathrm{a}}$ & $0.21 \pm 0.02^{\mathrm{b}}$ & $0.38 \pm 0.03^{\mathrm{b}}$ \\
\hline \hline
\end{tabular}

Values are means $(n=5) \pm S D$. (Values with different superscript are significantly different at $\mathrm{p}<0.05)$.

Group A: Control; Group B: Diabetic Control; Group C: Diabetic + (100 mg/kg body weight); Group D: Diabetic + (200 $\mathrm{mg} / \mathrm{kg}$ body weight); Group E: Diabetic + (300 mg/kg body weight); Group F: Diabetic + (5 mg/kg body weight of glibenclamide).

Table 6: Effect of administration of ethanolic extract of $M$. oleifera flower on the activity of superoxide dismutase of STZ-induced diabetic rats

\begin{tabular}{cccc}
\hline \hline \multicolumn{4}{c}{ SOD (U/mg protein) } \\
\hline Group & Liver & Kidney & Pancreas \\
\hline A & $1.40 \pm 0.09^{\mathrm{a}}$ & $24.43 \pm 2.25^{\mathrm{a}}$ & $17.34 \pm 0.75^{\mathrm{a}}$ \\
\hline B & $0.93 \pm 0.02^{\mathrm{c}}$ & $5.69 \pm 0.37^{\mathrm{d}}$ & $7.13 \pm 0.58^{\mathrm{c}}$ \\
\hline $\mathrm{C}$ & $1.13 \pm 0.07^{\mathrm{b}}$ & $17.64 \pm 1.60^{\mathrm{b}}$ & $8.20 \pm 0.82^{\mathrm{bc}}$ \\
\hline $\mathrm{D}$ & $1.17 \pm 0.05^{\mathrm{b}}$ & $18.55 \pm 1.56^{\mathrm{b}}$ & $12.11 \pm 1.02^{\mathrm{b}}$ \\
\hline $\mathrm{E}$ & $1.13 \pm 0.04^{\mathrm{b}}$ & $18.68 \pm 1.61^{\mathrm{b}}$ & $10.07 \pm 0.63^{\mathrm{b}}$ \\
\hline F & $1.20 \pm 0.05^{\mathrm{b}}$ & $11.00 \pm 1.05^{\mathrm{c}}$ & $13.14 \pm 0.84^{\mathrm{ab}}$ \\
\hline \hline
\end{tabular}

Values are means $(n=5) \pm S D$. (Values with different superscript are significantly different at $p<0.05)$.

Group A: Control; Group B: Diabetic Control; Group C: Diabetic + (100 mg/kg body weight); Group D: Diabetic + (200 $\mathrm{mg} / \mathrm{kg}$ body weight); Group E: Diabetic + (300 mg/kg body weight); Group F: Diabetic + (5 mg/kg body weight of glibenclamide). 
Table 7: Effect of administration of ethanolic extract of $M$. oleifera flower on the activity of catalase in the liver, kidney and pancreas of STZ-induced diabetic rats

\begin{tabular}{c|c|c|c}
\hline \multicolumn{5}{c}{ Catalase (U/mg) } \\
\hline Group & Liver & Pancreas & Kidney \\
\hline A & $7.52 \pm 3.70^{\mathrm{a}}$ & $8.56 \pm 3.44^{\mathrm{ab}}$ & $5.15 \pm 0.15^{\mathrm{a}}$ \\
\hline B & $1.65 \pm 0.41^{\mathrm{c}}$ & $3.13 \pm 0.59^{\mathrm{c}}$ & $1.92 \pm 0.04^{\mathrm{b}}$ \\
\hline C & $4.69 \pm 1.15^{\mathrm{b}}$ & $6.49 \pm 1.77^{\mathrm{b}}$ & $2.89 \pm 0.53^{\mathrm{ab}}$ \\
\hline D & $3.75 \pm 1.94^{\mathrm{b}}$ & $6.91 \pm 2.61^{\mathrm{b}}$ & $2.32 \pm 0.36^{\mathrm{ab}}$ \\
\hline E & $4.35 \pm 1.63^{\mathrm{b}}$ & $5.38 \pm 1.62^{\mathrm{bc}}$ & $2.97 \pm 0.15^{\mathrm{ab}}$ \\
\hline F & $3.89 \pm 0.95^{\mathrm{b}}$ & $9.18 \pm 1.39^{\mathrm{a}}$ & $3.17 \pm 0.005^{\mathrm{ab}}$ \\
\hline \hline
\end{tabular}

Values are means $(n=5) \pm S D$. (Values with different superscript are significantly different at $\mathrm{p}<0.05)$.

Group A: Control; Group B: Diabetic Control; Group C: Diabetic + (100 mg/kg body weight); Group D: Diabetic + (200 $\mathrm{mg} / \mathrm{kg}$ body weight); Group E: Diabetic $+(300 \mathrm{mg} / \mathrm{kg}$ body weight $)$; Group F: Diabetic + (5 mg/kg body weight of glibenclamide).

\section{Serum enzymes}

Table 8 presents the effects of oral administration of ethanolic extract of $M$. oleifera flower on alanine aminotransferase (ALT) activity in serum and liver of rats induced with diabetes using STZ. Serum alanine aminotransferase activity of all STZ-induced diabetic groups was not significantly different $(p>$ $0.05)$ from that of the control. There was also no significant difference $(p>0.05)$ in the liver alanine aminotransferase activity of all STZ-induced diabetic groups except group $B$ which had a significant increase $(p<0.05)$ with respect to the control.

Table 8: Effect of administration of ethanolic extract of M. oleifera flower on alanine aminotransferase activity of STZ-induced diabetic rats

\begin{tabular}{c|c|c}
\hline \multicolumn{3}{|c}{ ALT (IU/L) } \\
\hline Group & Serum & Liver \\
\hline A & $0.025 \pm 0.001^{\mathrm{ab}}$ & $0.427 \pm 0.03^{\mathrm{ab}}$ \\
\hline B & $0.027 \pm 0.001^{\mathrm{b}}$ & $2.64 \pm 0.05^{\mathrm{c}}$ \\
\hline C & $0.023 \pm 0.001^{\mathrm{ab}}$ & $0.12 \pm 0.07^{\mathrm{a}}$ \\
\hline D & $0.022 \pm 0.001^{\mathrm{a}}$ & $0.15 \pm 0.01^{\mathrm{a}}$ \\
\hline E & $0.025 \pm 0.001^{\mathrm{ab}}$ & $0.91 \pm 0.03^{\mathrm{b}}$ \\
\hline F & $0.023 \pm 0.002^{\mathrm{ab}}$ & $0.13 \pm 0.010^{\mathrm{a}}$ \\
\hline \hline
\end{tabular}

Values are means $(n=5) \pm S D$. (Values with different superscript are significantly different at $\mathrm{p}<0.05)$.

Group A: Control; Group B: Diabetic Control; Group C: Diabetic + (100 mg/kg body weight); Group D: Diabetic + (200 mg/kg body weight); Group E: Diabetic + $(300 \mathrm{mg} / \mathrm{kg}$ body weight); Group F: Diabetic + (5 mg/kg body weight of glibenclamide).
Table 9: Effect of administration of ethanolic extract of M. oleifera flower on aspartate aminotransfarase activity of STZ-induced diabetic rats

\begin{tabular}{c|c|c}
\hline \multicolumn{3}{c}{ AST (IU/L) } \\
\hline Group & Serum & Liver \\
\hline A & $0.035 \pm 0.001^{\mathrm{ab}}$ & $0.58 \pm 0.02^{\mathrm{a}}$ \\
\hline $\mathrm{B}$ & $0.0375 \pm 0.002^{\mathrm{b}}$ & $3.54 \pm 0.15^{\mathrm{b}}$ \\
\hline $\mathrm{C}$ & $0.0314 \pm 0.003^{\mathrm{ab}}$ & $0.16 \pm 0.11^{\mathrm{a}}$ \\
\hline $\mathrm{D}$ & $0.03 \pm 0.001^{\mathrm{a}}$ & $0.21 \pm 0.01^{\mathrm{a}}$ \\
\hline E & $0.034 \pm 0.002^{\mathrm{ab}}$ & $0.13 \pm 0.04^{\mathrm{a}}$ \\
\hline F & $0.032 \pm 0.002^{\mathrm{ab}}$ & $0.18 \pm 0.01^{\mathrm{a}}$ \\
\hline \hline
\end{tabular}

Values are means $(n=5) \pm S D$. (Values with different superscript are significantly different at $\mathrm{p}<0.05$ ).

Group A: Control; Group B: Diabetic Control; Group C: Diabetic + (100 mg/kg body weight); Group D: Diabetic + (200 mg/kg body weight); Group E: Diabetic + (300 mg/kg body weight); Group F: Diabetic + (5 mg/kg body weight of glibenclamide).

The effects of oral administration of ethanolic extract of $M$. oleifera flower on aspartate amino-transferase activity in serum and liver of rats induced with diabetes via STZ injection are shown in Table 9. Serum AST activity of all STZ-induced diabetic groups was not significantly different $(p>0.05)$ from that of the control. Liver AST activity of all STZ-induced diabetic groups was not significantly dif-ferent ( $p>0.05$ ) from that of the control except group B which had a significant elevation $(p<0.05)$. However, there was a significant decrease $(p<0.05)$ in the liver and serum aspartate amino-transferase activity of rats treated with ethanolic extract of $M$. oleifera flower. 
Table 10: Effect of administration of ethanolic extract of $M$. oleifera flower on alkaline phosphatase activity of STZ-induced diabetic rats

\begin{tabular}{c|c|c}
\hline \multicolumn{3}{c}{ ALP } \\
\hline Group & Serum & Liver \\
\hline A & $23.76 \pm 2.90^{\mathrm{ab}}$ & $143.95 \pm 11.11^{\mathrm{ab}}$ \\
\hline $\mathrm{B}$ & $28.47 \pm 2.32^{\mathrm{c}}$ & $251.03 \pm 18.00^{\mathrm{c}}$ \\
\hline $\mathrm{C}$ & $25.52 \pm 2.02^{\mathrm{b}}$ & $136.25 \pm 10.99^{\mathrm{ab}}$ \\
\hline $\mathrm{D}$ & $26.46 \pm 1.78^{\mathrm{ab}}$ & $179.53 \pm 15.41^{\mathrm{b}}$ \\
\hline $\mathrm{E}$ & $21.82 \pm 2.06^{\mathrm{a}}$ & $97.06 \pm 7.37^{\mathrm{a}}$ \\
\hline F & $18.61 \pm 1.85^{\mathrm{a}}$ & $136.91 \pm 10.10^{\mathrm{ab}}$ \\
\hline \hline
\end{tabular}

Values are means $(n=5) \pm S D$. (Values with different superscript are significantly different at $\mathrm{p}<0.05)$.

Group A: Control; Group B: Diabetic Control; Group C: Diabetic + (100 mg/kg body weight); Group D: Diabetic + (200 mg/kg body weight); Group E: Diabetic + $(300 \mathrm{mg} / \mathrm{kg}$ body weight); Group F: Diabetic + (5 mg/kg body weight of glibenclamide).

Table 10 displays the effects of oral administration of ethanolic extract of M. oleifera flower onalkaline phosphatase activity of STZ-induced diabetic rats. There was a significant decrease $(p<0.05)$ in the serum and liver alkaline phosphatase of the STZinduced diabetic groups when compared to the control. Serum and liver alkaline phosphatase activity of the untreated STZ-induced diabetic group was significantly increased $(p<0.05)$, while ALP activity in the groups treated with ethanolic extract of $M$. oleifera flower was significantly decreased.

\section{DISCUSSION}

\section{Phytochemical constituents}

Results of the phytochemical screening shows the presence of alkaloids and flavonoids which have been implicated as possible bioactive agents leading to toxicological and antidiabetic effects (34). Basically, flavonoids are best known for their antidiabetic properties which agree with the report of Soliman (35) that $M$. oleifera flowers possess antioxidant and antidiabetic activity owing to the presence of flavonoids. Although the hypoglycemic effect of terpe-noids appear to involve stimulation of pancreatic $\beta$-cells and subsequent secretion of preformed insulin (36), one or more other chemical constituent(s) of the flower especially is/are also likely to have played a prominent part in the hypoglycemic action of the flower extract and may be involved in the alterations of biochemical parameters in this present study.

Blood glucose and antidiabetic studies

Diabetes mellitus is a chronic disease characterized by high blood glucose levels as a result of absolute or relative deficiency of circulating insulin levels. In this study, rats induced with diabetes via STZ injection exhibited a significant increase $(p<0.05)$ in blood glucose level which corresponds to the report of Ghada (35) and Tendelet al. (37) on streptozotocininduced diabetes. According to Ghada (35) and Tendelet al. (37), the elevated glucose level may be attributed to destruction of pancreatic $\beta$-cells by STZ, causing a notable reduction in insulin release by pancreatic $\beta$-cells. Studies have shown that a variety of plant part extracts are able to effectively reduce blood glucose level in STZ-induced diabetic rats (38). Ethanolic extract of $M$. oleifera flower demonstrated glucose-lowering effect in hyper-glycaemic rat possibly through the stimulation of $\beta$-cells and/or as a result of its insulin-like activity. The possible mechanism of hypoglycaemic action of the ethanolic extract of M. oleifera flower may be via potentiation of insulin secretion from $\beta$-cells of the islets of Langerhans or as a result of improved blood glucose transport to peripheral tissues (39).

Antioxidants provide defence against degenerative diseases such as cancer, Alzheimer's diseases, and coronary heart disease (6). Antioxidants expressed their protective actions through the repression of ROS formation, inhibition of enzymes and chelation of elements required for free-radical production, scavenging reactive species, and up regulation of antioxidant defenses (10). The antioxidant enzyme superoxide dismutase (SOD) has been described as the first line of defense enzymes against free radicals (35). In this study, the significant elevation in activity of liver superoxide dismutase (SOD) with a significant elevation in liver, pancreas and kidney malondialdehyde (MDA) concentration of rats induced with diabetes via STZ injection can be attributed to large free radicals produced by the hyperglycaemic condition. It was observed that treatment with ethanolic extract of M. olifera flowers significantly increased SOD and significantly decreased MDA levels in STZinduced diabetic rats. This shows that the ethanolic extract possesses the potential to lower reactive free radical levels which may ameliorate oxidative dama- 
ge and this may be traceable to the rich presence of flavonoids which have antioxidant property (35). $M$. oleifera is a rich source of anti-oxidants (25-27) which are largely responsible for its antioxi-dant activity (4041).

\section{Serum lipid profile}

Concentrations of total cholesterol, TG, HDL/LDL ratio and coronary risk indices (CRI) are indicators of susceptibility to cardiovascular diseases (CVDs) (42). The marked reduction of these parameters in STZ-induced diabetic rats administered the extract compared to those administered glibenclamide demonstrates the potential of ethanolic ex-tract of $M$. oleifera flower to reduce the risk of CVDs. Treatment of diabetes mellitus with the extract could therefore prevent and/or reduce the risk of cardiovascular complications of diabetes. Diabetics usually have smaller, densely oxidized LDL molecules, which may elevate atherogenicity even if the absolute LDL cholesterol concentration is not increased (42). This study also shows significantly elevated levels of triglyceride in diabetic rats in relation to the controls. Triglyceride levels were significantly reduced following the treatment with ethanolic extract of $M$. oleifera flower. Thus, by suppressing diabetes-induced elevation in lipid levels, ethanolic extract of M. oleifera flower may be useful in the reduction of the risk of cardiovascular complications of diabetes.

Enzymes studied

Elevated levels of aminotransferases in the serum are a common sign of liver and kidney damage and are observed more often among diabetics than in the general population (43). This study shows that the levels of liver aminotransferase (ALT and AST) increased significantly in STZ-induced diabetic untreated rats as shown in Tables 7 and 8, respectively. The increase in aminotransferase levels may be attributed to cellular damage in the liver induced by diabetes. Cell damage results to increased permeability leading to the leakage of cytosolic enzymes into the blood (44). However, ethanolic extract of $M$. oleifera flower produced a marked significant decrease of the elevated AST and ALT activities. This decrease may be attributed to the hepatoprotective and antioxidant activity of a number of flavonoids in the ethanolic extract of $M$. oleifera flower. This agrees with the report of Ghada (35) where it was reported that the effect of STZ-diabetes on ALP activity revealed a significant increase in ALP activity of STZinduced untreated rats. A marked decrease of serum and liver ALP activity of STZ-induced rats after treatment with ethanolic extract of Moringa-oleifera indicates its protective effect over liver and improvement in liver function efficiency.

\section{CONCLUSION}

The present study showed that ethanolic extract of M. oleifera flower possesses hypo- and normoglycemic properties in rats induced with diabetes via STZ injection. This indicates that the ethanolic extract of $M$. oleifera contains biologically active components. Different doses of the plant extract used in this study demonstrated hypolipidemic and antioxidant abilities of the flower. This suggests its efficacy in the maintenance of glucose homeostasis and may be used as a therapeutic alternative in the management of diabetes mellitus. It also has beneficial effect on various metabolic and enzymatic functions of the liver in STZ-induced diabetic rats. 


\section{References}

1. Gandhipuram P, Sentil K, PalanisamyA et al. Antidiabetic Activity of fruits of Terminaliachebula on STZ induced diabetic rats. JHealthSci 2006; 52: 283-91.

https://doi.org/10.1248/jhs.52.283

1. Shaw JE, Sicree RA, Zimmet PZ. Global estimates of the prevalence of diabetes for 2010 and 2030 . Diabetes Res ClinPract 2010; 87:4-14. https://doi.org/10.1016/j.diabres.2009.10.007

2. Barik R, Jain S, Qwatra D et al. Antidiabetic activity of aqueous root extract of Ichnocarpusfrutescens in STZ-nicotinamide induced type II diabetes in rats. Indian JPharmacol. 2008; 40: 1922. https://doi.org/10.4103/0253-7613.40484

3. Vincent AM, Russell JW, Low P et al. Oxidative stress in the pathogenesis of diabetic neuropathy. Endocr. Rev. 2004; 25: 612-28. https://doi.org/10.1210/er.2003-0019

5. Pari L, Latha M. Antidiabetic effect of Scopariadulcis: effect on lipid peroxidation in streptozotocin diabetes.

GenPhysiolBiophys.2005; 24: 13-26.

6. Heim KE, Tagliaferro AR, Bobilya DJ. Flavonoid antioxidants: chemistry, metabolism and structure activity relationships. J NutrBiochem. 2002;13:572- 584.

https://doi.org/10.1016/S0955-2863(02)00208-5

7. Picton SF, Flatt PR, McClenghanNH. Differential acute and long term actions of succinic acid monomethyl ester exposure on insulin secreting BRAIN-BD 11 cells.IntJExpDiab Res 2001; 2: 1927.

https://doi.org/10.1155/EDR.2001.19

8. Iqbal S, Bhanger M. Effect of season and production location on antioxidant activity of
Moringaoleifera leaves grown in Pakistan. J Food Comp Anal. 2006;19:544-51.

https://doi.org/10.1016/j.jfca.2005.05.001

9. Arise RO, Aderounmu IG, Oguntibeju OO. Lipid Profile, Antidiabetic and Antioxidant activity of Acacia ataxacantha Bark extract in Streptozotozin-induced Diabetic Rats. Intech Open Science/Open Minds 2014

10. Arise RO, Malomo SO, Adebayo JO, et al. Effects of aqueous extract of Eucalyptus globules on lipid peroxidation and selected enzymes of rat liver. J Med Plant Res. 2009: 077081.

11. Fahey JW, Haristoy X, Dolan PM, et al. Sulforaphane inhibits extracelular, intracellular, and antibiotic-resistant strains of helicobacter pylori and prevents benzo (a) pyrene induced stomach tumours. ProcNatlAcadSci U.S.A 2002; 99: 7610-15.

https://doi.org/10.1073/pnas.112203099

12. Guevara AP, Vargas C, Sakurai H. An antitumor promoter from $M$. oleifera Lam. Mutat Res 1999; 440:181 - 8 .

https://doi.org/10.1016/S1383-5718(99)00025-X

13. Akhtar AH, Ahmad KU. Anti-ulcerogenic evaluation of the methanolic extract of some indigenous medicinal plants of Pakistan in aspirin-ulcerated rats. J Ethnopharmacol.1995; 46: 1-6.

https://doi.org/10.1016/0378-8741(94)01220-T

14. Rao CV, Ojha SK. Analgesic effect of Moringaoleifera Lam., leaf extract on rats, 2nd World congress on Biotechnological Developments of Herbal Medicine: Luck Now. India:NBRI 2003:42

15. Bennett RN, Mellon FA, Foidl N et al. Profiling glucosinolates and Phenolics in Vegetative and 
Reproductive tissues of the multi-purpose trees Moringaoleifera L. (Horseradish tree) and Moringastenppetala L. JAgric Food Chem. 2003; 51: 3546-53.

\section{https://doi.org/10.1021/if0211480}

16. Sharma $\mathrm{P}$, Kumari $\mathrm{P}$, Srivastava $\mathrm{MM}$ et al. Removal of cadmium from aqueous system by shelled M. oleifera Lam. seed powder. Bioresour Technol. 2006; 97:299 - 305.

https://doi.org/10.1016/j.biortech.2005.02.034

17. Makonnen E, Hunde A, Damecha G. Hypoglycaemic effect of $\mathrm{M}$. stenopetala aqueous extract in rabbits. Phytother Res. 1997; 11:147-8.

https://doi.org/10.1002/(SICI)1099$\underline{\text { 1573(199703)11:2<147::AID-PTR41>3.0.CO;2-V }}$

18. Pal SK, Mukherjee PK, Saha BP. Studies on the antiulcer activity of $M$. oleifera leaf extract on gastric ulcer models in rats. Phytother.Res 1995; 9:463-5.

https://doi.org/10.1002/ptr.2650090618

19. Caceres A, Saravia A, Rizzo S et al. Pharmacological properties of Moringaoleifera 2: Screening for antispasmodic, anti-inflammatoy and diuretic activity. J. Ethno-pharmacol 1992; 36:233 - 237.

https://doi.org/10.1016/0378-8741(92)90049-W

20. Morton JF. The horse radish tree: $M$. pterigosperma (Moringacea). A boon to arid lands.Economic Botany 1991; 45:318 - 33.

https://doi.org/10.1007/BF02887070

21. Dahot MU. Vitamin contents of flowers and seeds of M. oleifera.Pak. JBiochem 1988; 21:1 -24.

22. Mehta LK, Balaraman R, Amin AH et al. Effects of fruits of $M$. oleifera on the lipid profile of normal and hypercholesterolaemic rabbits. JEthnopharmacol 2003; 86:191 - 5 .

https://doi.org/10.1016/S0378-8741(03)00075-8

23. Ruckmani, K, Kavimani S, Anandan $\mathrm{R}$ et al. Effect of Moringaoleifera Lam on paracetamol induced hepatoxicity. Indian J. Pharm. Sci 1998; 60:33- 5 .
24. Nickon F, Saud ZA, Rehman MH et al. In vitro antimicrobial activity of the compound isolated from chloroform extract of M. oleifera Lam. Pak. JBiol Sci. 2003; 22:1888- 1890.

25. Kumar PS, Mishra D, Ghosh G et al. Medicinal uses and pharmacological properties of Moringaoleifera. Int. J. Phytomed 2010; 2: 21016.

26. Amaglo NK, Bennett RN, Lo Curto RB et al. Profiling selected phytochemicals and nutrients in different tissues of the multipurpose tree Moringaoleifera L., grown in Ghana. Food Chem 2010; 122: 1047-54.

https://doi.org/10.1016/j.foodchem.2010.03.073

27. Gowrishankar R, Kumar M, Menon V et al. Trace element studies on Tinospora cordifolia (Menispermaceae), Ocimum sanctum (Lamiaceae), M. oleifera (Moringaceae), and Phyllanthus niruri (Euphorbiaceae) using PIXE. Biol Trace Elem Res 2010; 133: 357-63.

https://doi.org/10.1007/s12011-009-8439-1

28. Sofowora A. Medicinal plants and Traditional Medicine in Africa.2nd edition. Spectrum Books Limited (Publisher), Ibadan, Nigeria, 1993: 13456.

29. Jiang ZY, Hunt JV, Woff SP. Ferrous ion oxidation in the presence of xylenol orange for detection of lipid peroxide in low density lipoprotein.Anal Biochem 1992; 202:384-9.

https://doi.org/10.1016/0003-2697(92)90122-N

30. Aebi H. In: Bergmeyer HU, (ed). Methods of Enzymatic Analysis. New York: Chemic Academic Press, 1974: 673-85.

https://doi.org/10.1016/B978-0-12-091302-2.50032-3

31. Misra H, Fridovich I. The Role of Superoxide Anion in the Autooxidation of Epinephrine and a Simple Assay for Superoxide Dismutase, J BiolChem 1972; 247-3170.

32. Wright PJ.,Leathwood PD, Plummer DT. Enzymes in rat urine Alkaline phosphatase. Enzvmologia 1972; 42: 317-327.

33. Mahajan BK. Significance of difference in means in methods in Biostatic for Medical Works, 6th 
Edition. New Delhi JAYPEE Brothers Medical Publisher, 1997: 130-55.

34. Coman C, Rugina OD, SocaciuC. Plants and natural compounds with antidiabetic action.Not Bot HortiAgrobo. 2012; 40(1): 314-25.

35. Ghada Z, Soliman A. Anti-Diabetic Activity of Dried Moringaoleifera Leaves in Normal and Streptozotocin (Stz)-Induced Diabetic Male Rats. Indian J.A.R. 2013; 3:18-22

36. Ojowole, JOA. Hypoglycemic effect of Clausenaanisata(Willd) hook methanolic root extract in rats. J. Ethnopharmacol. 2002; 81: 231-7.

https://doi.org/10.1016/S0378-8741(02)00085-5

37. Tende JA, Ezekiel I, Dikko AAU et al. Effect of Ethanolic Leaves Extract of Moringaoleifera on Blood Glucose Levels of Streptozocin-Induced Diabetics and NormoglycemicWistar Rats. Br J.Pharmacol.Toxicol. 2011; 2: 1-4.

38. Rajasekaran S, Sivagnanam K, Subramanian S. Antioxidant effect of Aloe vera gel extract in streptozotocin-induced diabetes in rats. Pharmacol. Rep 2005; 57: 90-6.

39. Doda RF. Diabetic mellitus, In: Kaplan LA, Amadeo JP, (eds). Clinical Chemistry. St Louis: Mosby Year Book, 1996: 613-41.
40. Siddhuraju P and Becker K. Antioxidant properties of various solvent extracts of total phenolic constituents from three different agroclimatic origins of drumstick tree (Moringaoleifera Lam.) leaves. J Agric Food Chem. 2003; 51: 2144-55.

https://doi.org/10.1021/jf020444+

41. Bajpai M, Pande A, Tewari SK et al. Phenolic contents and antioxidant activity of some food and medicinal plants. Int J Food SciNutr 2005; 56: 287-91.

https://doi.org/10.1080/09637480500146606

42. Lamarche B, Tchernof A, Moorjni S et al. Small, dense, low-density lipoprotein particles as a predictor of the risk of ischemic heart disease in men: Prospective results from the Quebec Cardiovascular study. Circulation 1997; 95: 6975.

https://doi.org/10.1161/01.CIR.95.1.69

43. Sivajothi, V, Dey,A; Jayakar,B,Rajkapoor B. Antihyperglycemic property of Tragiacannabina in streptozotocin-induced diabetic rats. J. Med. Food 2007; 10:361-5.

https://doi.org/10.1089/jmf.2006.030

44. Garella S. The cost of dialysis in the USA.Nephrol. Dial. Transplant 1997; 12:10-21. 


\title{
Antidijabetična i antioksidativna svojstva etanolskog ekstrakta suvih cvetova Moringa oleifera kod miševa sa dijabetesom izazvanim streptozotocinom
}

\author{
Rotimi Olusanya Arise ${ }^{1}$, Oluwaseun Ruth Aburo, ${ }^{1,2}$, Samuel Tobi Farohunbi ${ }^{1}$, \\ Adenike Adebola Adewale ${ }^{1,3}$ \\ ${ }^{1}$ Departman zabiohemiju, Univerzitet u Ilorinu, P.M.B. 1515, Ilorin, Nigerija \\ ${ }^{2}$ Departman zabiohemiju, UniverzitetAfeBabalola, Ado Ekiti, Ekiti, Nigerija \\ ${ }^{3}$ Departman zabiohemiju, Univerzitet Bowen, Iwo, DržavaOsun, Nigerija
}

\section{SAŽETAK}

Cilj ove studije bio je utvrđivanje antidijabetičnih i antioksidativnih efekata oralno datog etanolskog ekstrakta cvetova Moringa oleifera kod miševa sa dijabetesom izazvanim streptozotocinom u dozi od 100, 200, i $300 \mathrm{mg} / \mathrm{kg}$ telesne mase.

Trideset (30) eksperimentalnih belih miševa muškog pola nasumično je podeljeno u šest grupa: A, B i F su označavale kontrolnu, dijabetičnu kontrolnu i referentnu grupu koja je primala lek, dok su grupe označene od C do E primile dozu ekstrakta od 100, 200 i $300 \mathrm{mg} / \mathrm{kg}$ telesne mase. Uzorci krvi i organa su sakupljani zbog analiza nivoa glukoze $i$ antioksidativnih enzima.

Nivoi glukoze u krvi, serumskih lipida i lipidne peroksidacije, kao i aspartata aminotransferaze (AST), alkalne fosfataze (ALP) i alanin aminotransferaze (ALT) bili su značajno smanjeni $(p<0,05)$ kod miševa sa dijabetesom izazvanim streptozotocinom kojima je oralno dat etanolski ekstrakt cveta M. oleifera. Međutim, telesna masa i aktivnost katalaze i superoksid dismutaze bili su značajno povećani $(p<0,05)$ kada se uporede sa kontrolnim grupama.

Etanolski ekstrakt cveta M. oleifera dat oralno poboljšao je metabolizam masti, uticao na smanjenje nivoa glukoze i pokazao blagotvorna svojstva u preveniranju komplikacija dijabetesa, što je rezultat lipidne peroksidacije i oksidativnih sistema kod miševa sa dijabetesom izazvanim streptozotocinom. It tog razloga se može koristiti u terapeutske svrhe za lečenje dijabetesa melitusa.

Ključne reči: etanolski ekstrakt, antidijabetični, antioksidativni enzimi, Moringa oleifera, streptozotocin 
Original article 